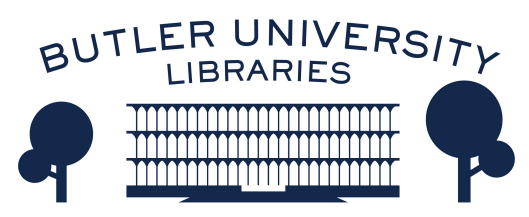

Journal of Hindu-Christian Studies

Volume 15

Article 16

January 2002

\title{
Book Review: "Crossing the Borders: Essays in Honour of Francis $X$. D'Sa on the Occasion of his 65th Birthday"
}

\author{
J.T.K. Daniel
}

Follow this and additional works at: https://digitalcommons.butler.edu/jhcs

Part of the Religion Commons

\section{Recommended Citation}

Daniel, J.T.K. (2002) "Book Review: "Crossing the Borders: Essays in Honour of Francis X. D'Sa on the Occasion of his 65th Birthday"," Journal of Hindu-Christian Studies: Vol. 15, Article 16.

Available at: https://doi.org/10.7825/2164-6279.1283

The Journal of Hindu-Christian Studies is a publication of the Society for Hindu-Christian Studies. The digital version is made available by Digital Commons @ Butler University. For questions about the Journal or the Society, please contact cbauman@butler.edu. For more information about Digital Commons @ Butler University, please contact digitalscholarship@butler.edu. 


\section{BOOK REVIEWS}

\section{Crossing the Borders: Essays in Honour of Francis X. D'Sa on the Occasion of his 65th Birthday. Anand Amaladass and Rosario Rocha (Eds.). Chennai: Satya Nilayam Publications, 2001, xiv + $421 \mathrm{pp}$.}

THIS FESTSCHRIFT contains 25 chapters, including the response of the 'boundary crosser' Father Francis D'Sa S.J., himself. Apart from the Editors' Introduction the volume is divided into four parts as Crossing the Borders- across religions, traditions, Christian theologies and interdisciplinary sciences. It ends with an Epilogue. The common message of all these essays by distinguished scholars is that in order to promote harmony and peace in a pluralistic society people have to transcend the fundamentalist tendency. In other words, in order to be meaning makers in the contemporary world, it is essential for us to cross the borders. Jesus' call to love one's neighbour as himself/ herself is indeed a praxiological approach as rightly pointed out by the editors. [xiv]. We shall make a brief sample survey of the many suggestions presented in the four areas of crossing the borders in this important publication

First, in crossing the borders across religions, Raimon Panikkar claims the importance of dialogue to become a dialogal duologue, as the language for communication between any two religions cannot be fixed a priori mainly to preserve objectivity. For any participation in dialogue, subjectivity cannot be excluded. "A real dialogue has to be human, and Man is more than reason alone."[10]. According to Michael Amaladoss, religious conversion should be taken as one "answering a special call of God" rather than crossing borders put up by structures of religious traditions, as we continue to live for all practical purpose in an inter-dependent religious world which has no borders.[p.24].

Second, in crossing the borders across traditions, Siegfried Wiedenhofer examines the boundaries of traditions and, in particular, the whole range of meanings of the word tradition. He puts the emphasis not only on the importance of both "boundaries and openness" so that people do not become petrified, but also on a proper and clear explanation of the boundaries of the tradition. Anand Amaladass gives an interpretation of crossing the traditions using an indigenous expression digvijaya, borrowed from Mahabharata, in order to portray how the ancient as well as modern leaders of the Indian society inextricably intertwine politics and religion in the conquest of new territories. $\mathrm{He}$ adds that crossing the borders is "a way of enriching oneself, widening one's horizons, broadening one's knowledge, discovering oneself in this process." [167].

Third, in crossing the borders across Christian theologies, Josef Hainz explains exegetically the earliest account of the Institution of the Lord's Supper, given in I Corinthians Chapter 11 of the New Testament and establishes the importance of the ecumenical celebration of the sacrament of the Lord. The application of the scripture is "not only to the beginnings but also on principle."[223]. The common celebration of the Eucharist can certainly bring all Christian communities together, transcending the denominational barriers, which have been erected in spite of the Lord's prayer for unity among all His 
disciples on the night of instituting the sacrament.

According to Jacob Kavunkal, "revisioning of Christian identity" across the religious borders may be possible if we take seriously "the fragrance of Jesus Christ" as the paradigm for contemporary mission.[315]. We are aware that the Son of God did not stay in the safe immunity of his heaven, remote from human alienation of oneself from the Creator, one's neighbour and the rest of creation. Jesus Christ emptied himself of his glory and humbled himself to serve the humanity like a slave and to die on the cross for their redemption. The values of the kingdom, which he shared through his teachings, are all perfect human values. He penetrated deeply into our humanness. $\mathrm{He}$ became friend of sinners and the dropouts of society. He touched the untouchables. Crossing the borders for him was total identification of love. As a matter of fact, "Christian history is replete with examples of momentous border crossings" since its inception, as rightly observed by Isaac Padinjarekuttu. [326]

Fourth, crossing across interdisciplinary sciences is essential in our time to protect humane values of our civilization. For example, crossing the borders between religion and science cannot be any longer an option, but an obligation. Otherwise, in the name of scientific research, "the rightful human dignity and important human concerns" are likely to be "mortgaged by developments in genome research and genetic engineering." [347]

To those committed to one religion or tradition, it may not be easy to cross their borders and to identify themselves with people of other traditions and beliefs. But, in order to be enriched in our lives we need to take the difficult path of reconciliation, by dying to ourselves. In the words of Father Francis D'Sa, "...crossing is basically a cross, that is a sign of life, that makes us give up the old and enter the new, that makes us go through death to life." [407]. In other words, though the cross of Christ portrays the most hopeless situation in human viewpoint, it has become the very foundation for our hope and faith.

Crossing the Borders calls the readers to take the risk of losing one's identity and to transcend the most intransigent walls erected in our society in the name of religion and culture. I trust that many readers of this volume would find it a helpful tool for inspiring them to cross the many barriers, dividing the humanity.

I congratulate the editors, authors of various chapters and the publisher on bringing out this timely contribution, which promotes shalom in the beginning of the 21st Century.

J.T.K. Daniel, Ph. D., Former Principal of Serampore College

\section{Jules Monchanin (1895-1957) as Seen from East and West, volumes 1 and 2. English translation edited by Thomas Matus, O.S.B. Cam. and Sister Sarananda, O.S.B. Delhi: ISPCK and Saccidananda Ashram, 2001, 200 and 153 pp.}

THESE TWO VOLUMES offer a detailed and intriguing portrait of a 20th century Western pioneer in the Hindu-Christian dialogue who, though perhaps less well known than his successors, nevertheless merits both scholarly attention and critical appraisal. 